\title{
Instinct and Explanation in Thomas Reid's Theory of Action
}

\section{Introduction}

In his account of what he calls the 'mechanical principles' of action, Thomas Reid distinguishes between deliberate, willed actions and those caused by instincts or habits. He holds that that agents can only be held morally responsible with respect to willed actions, as it is only in such cases that the agent acts freely on his libertarian model of agency. Nevertheless, in his later writings Reid seems to suggest that instinctual behaviour is both prior to and a precondition for the performance of free action. In this brief paper, I want to first introduce Reid's theory of action and then expand upon this account in order to show that it goes some way to mitigate the criticisms raised by Louis Loeb and others against Reid, namely that Reid is content to rest with an account that rejects any attempt to explain the origin of beliefs that arise from human nature. Loeb portrays Hume as the superior philosopher due in part to his willingness to open up the black box of the mind for scientific inspection. I want to claim that Loeb misses the mark here; despite the fact that Hume does attempt to give us a psychological account of the origins of certain beliefs, it is crippled by the implausible restrictions Hume places on his system. Reid's account, in contrast, employs a different conception of explanation and, as a result, offers a more plausible account that is not hindered by an unnecessary emphasis on introspection. 


\section{Agents, First Principles and Free Action}

Aside from his common sense epistemology, Thomas Reid is possibly best known for his libertarian, agent causalist account of human action. Agents are uncaused causes of their volitions for Reid: when one initiates an act, at least under certain conditions, one is not caused to do so. Correspondingly, at least some of one's actions are not determined either by prior states external to, or internal to, oneself. Where, in an act of throwing a ball, the deliberate movement of my arm is caused by a volition, only I can be said to be the true cause of the movement, and to be morally responsible for the consequences of the thrown ball as its path intersects a neighbour's window. Nothing in the prior history of the external world or my psychology determined that I will that particular volition at that particular time. To hold this is to hold that agents possess active power. Just what this is cannot be defined, according to Reid: it does not follow, however, that we do not have a conception of it. We have, "very early, from our constitution, a conviction or belief of some degree of active power in ourselves": there is a "principle, which appears very early in the mind of man, is, that we are efficient causes in our deliberate and voluntary actions" (EAP 4.2). ${ }^{1}$

The freedom of the will is accordingly one of Reid's first principles of contingent truth, the sixth in Reid's list of fourteen:

6. Another first principle, I think, is, That we have some degree of power over our actions, and the determinations of our will. (EIP 6.5)

The principles Reid is interested in uncovering are those principles to which all of mankind are committed, arising as they do directly from our shared human nature. These principles are not learned or acquired from experience, nor were they discovered at some prior point in human history. Such principles are implicit in the structure of all languages; thus all societies and cultures share a pretheoretical commitment to the beliefs. They have "the consent of ages and nations, of the learned and unlearned" (EIP 6.4). Such principles are self-evidently true in the sense that reflection on them commands assent (though, of course, one can call them into question or submit them to sceptical challenge, as Reid's contemporary and main foil Hume clearly demonstrates).

1 I will follow standard practice by citing passages from the Essays on the Active Powers of Man (1788) (henceforth 'EAP') and the Essays on the Intellectual Powers of Man (1785) ('EIP') by reference to essay, (part, where applicable) and chapter. Passages from An Inquiry into the Human Mind on the Principles of Common Sense (1764) ('IHM') are cited by chapter and section. 
Reid's first principles do not admit of proof: in a nutshell, there is nothing more fundamental that could play a justificatory role with regard to belief in a first principle. Our capacity for reason, the reliability of perceptual experience, the reliability of causal reasoning - these are all first principles and thus have the same epistemic status. No one first principle can serve to justify another. They have to be identified through their possession of the characteristic traits noted above. The identification of a first principle thus involves linguistic, sociological and historical investigation, as well as introspective reflection upon one's own doxastic commitments.

As James Harris notes, these considerations are not intended to prove a first principle; as just mentioned, the principles are fundamental and do not admit of proof. Instead, they "show that philosophy can be brought to bear on the task of distinguishing genuine first principles from mere pretenders to that status" (Harris, 186); they are not for the purpose of showing that such principles are true. To go briefly beyond the scope of the present paper, Reid thinks that we are committed to taking such principles as true. To reject some but to retain others is to display and illegitimate and ungrounded favouritism, as all the principles come from the "same shop" (IHM 6.20) and thus deserve equal credence; to reject all is to depart from the realm of philosophy and rationality entirely.

Returning to the matter of the belief in one's possession of active power, Reid offers five considerations in support of the contention that this is a first principle:

The arguments I have adduced are taken from these five topics: 1 . That there are many things that we can affirm or deny concerning power, with understanding. 2. That there are, in all languages, words signifying, not only power, but signifying many other things that imply power, such as, action and passion, cause and effect, energy, operation, and others. 3. That in the structure of all languages, there is an active and passive form in verbs and participles, and a different construction adapted to these forms, of which diversity no account can be given, but that it has been intended to distinguish action from passion. 4 . That there are many operations of the human mind familiar to every man come to the use of reason, and necessary in the ordinary conduct of life, which imply a conviction of some degree of power in ourselves and In others. 5. That the desire of power is one of the strongest passions of human nature. (EAP 1.2 pp. 19-20)

Here we see Reid offering evidence of all the sorts mentioned above in support of the claim that one's belief that one possesses active power is a first principle. The distinction between active and passive verbs reflects a commitment to the distinction between the actor and those acted 
upon, a distinction found across all cultural and linguistic borders. We display a prephilosophical commitment to the existence of such power in ourselves and others, as when I believe in my power to stand up, or turn the light off, or reach the bus station by six o'clock. Note, too, that on Reid's account the desire for power just is the desire that one's active power be more efficacious or have greater reach. What, though, is it to possess this active power?

Reid is committed to a two-way conception of power: an agent possesses active power if and only if she is able both to will to perform an action and to refrain from willing to do so. The free agent can perform an action or refrain from doing so in the same set of circumstances, where these circumstances include her possession of just those preferences and desires. The totality of her psychological states does not entail that she attempts to engage in a particular course of action. In other words, should she choose to, the free agent can act against her own desires; her desires do not determine her behaviour. Preferences, desires, sentiments, beliefs - no combination of these psychological states can entail that a free agent act in a particular manner. Should there be such an entailment, then the agent is not free with respect to that action. As noted above, the Reidian agent is thus truly an uncaused cause.

Reid, therefore, is an agent-causalist: the true causes of human actions are agents, not prior events (irrespective of whether these are construed as located internally or externally to the subject). William L. Rowe summarises Reid's position thus:

On Reid's view of agent-causation, the following three conditions are necessary and sufficient for $X$ to be an agent-cause of some event e:

1. X is a substance that had power to bring about $\mathrm{e}$.

2. X exerted its power to bring about e.

3. $\mathrm{X}$ had the power to refrain from bringing about $\mathrm{e}$.

(Rowe, 227)

The notion of liberty to which Reid's account of power gives rise is implicit in the preceding. It is only where one possesses this active power with respect to a particular action that one can be said to possess liberty, to be a free agent.

By the Liberty of a Moral Agent, I understand, a power over the determinations of his own Will.

If, in any action, he had power to will what he did, or not to will it, in that action he is free. But if, in every voluntary action, the determination of his will be the necessary consequence of something involuntary in the state of his mind, or of something in his external circumstances, he is not free; he has not what I call the Liberty of a Moral Agent, but is subject to Necessity. (EAP 4.1) 
An agent might possess liberty with respect to certain actions, yet be subject to necessity in the case of others. It might well be the case that I acted freely when I purchased the excessively large bar of chocolate - I did not experience myself as determined to do so, I seriously contemplated buying other alternatives in its place, in similar circumstances I do not always buy absurd quantities of chocolate, etc. - but that does not entail that I acted freely when eating the whole bar against my better judgement. The consumption of the first half of the bar might have triggered some compulsive or addictive behaviour that left me determined to continue until the chocolate was no more. The addict's injecting himself with heroin is most likely an unfree act; his decision what to wear on the way to meeting his dealer, less so.

The exertion of active power, and thus the liberty of a moral agent, has an important intellectual dimension. One cannot be free in this sense if one does not possess some grasp of what it is that one is seeking to achieve and of how one might go about achieving it. Liberty requires understanding on the part of the agent, in that a volition presupposes a conception of its object, the action it is intended to bring about:

This liberty supposes the agent to have understanding and will; for the determinations of the will are the sole object about which this power is employed; and there can be no will without such a degree of understanding, at least, as gives the conception of that which we will.

The liberty of a moral agent implies, not only a conception of what he wills, but some degree of practical judgment or reason. (EAP 4.1)

So, Reid holds that a free action - that is, an action for which the agent is morally responsible - is an action that the agent willed but could have refrained from willing, involving a goal that the agent possessed a conception of at the time at which she acted and an exercise of practical reason. I am responsible for shattering the window with the kicked ball; a new-born infant is not responsible for punching its parent on the nose, as it had no conception of what would happen (even at the level of basic bodily movement) when it exerted itself in just that way.

We should not think that Reid's account of human behaviour is excessively intellectualised, however. Yes, we do engage in careful, deliberate actions that see us grasp our goals, plan a course of action and choose to act (to exercise our active power) in pursuit of those goals, but plausibly the largest part of our day to day behaviour is not of this sort. We engage in habitual behaviour, act without deliberation or conscious planning, unreflectively respond to hunger, itches and other stimuli. Not all human activity, to put it in Reidian terms, involves the exercise of active power alongside a conception of one's aims and a practical judgement; indeed, any account that claimed that all human activity possessed these characteristics would be an exceedingly poor theory of human nature. 
Reid, the astute observer of humankind, is well aware of this. He recognises that there are other forms of activity, broadly construed, that human beings engage in. Reid spends the largest part of his third of his Essays on the Active Powers on non-rational principles of action and divides these into the mechanical and the animal principles of action. The mechanical principles of action include instinct and habit; the animal principles include appetites, benevolence, passion, disposition. In the following, we need only need draw upon the former.

Here are Reid's characterisations of the two mechanical principles:

By instinct, I mean a natural blind impulse to certain actions, without having any end in view, without deliberation, and very often without any conception of what we do. (EAP 3.1.2)

Habit: acquired, rather than natural. "Both operate without will or intention, without thought, and therefore may be called mechanical principles." (EAP 3.1.3)

We will return to the role of instinct, this "blind impulse", below.

\section{The Explanation of First Principles (or the Lack Thereof)}

As seen above, Reid thinks that first principles do not admit of proof or justification. They are foundational, and the belief in them ungrounded and instinctual, arising directly from human nature. As recent commentators have noted, this appears closer to Hume's account of the origins of our core beliefs than Reid himself appears to notice. Our utilisation of causal explanations and of induction, our beliefs in the existence of the self and of the external world, all of these stem from the ultimately irresistible operation of the imagination, according to Hume. Human nature has not left it up to us to decide whether or not we should accept that food that nourished us one day will continue to do so on another. This is, of course, the naturalistic turn in Hume, and it is a move that Reid does not discuss, choosing instead to focus on Hume's apparently sceptical conclusions, as Loeb points out. Nevertheless - unsurprisingly - there are differences between the accounts of the two contemporaries. These include differences concerning the justificatory status of the principles: is belief in the deliverances of human nature warranted as well as unavoidable?; do these natural beliefs transmit warrant to further beliefs?, etc. The difference that concerns us here does not relate to the epistemic status of the first principles, however. Rather, the difference, latched on to by Loeb, concerns the attitudes of Reid and Hume to the explanation of beliefs of this kind: Hume explains the origins of such beliefs (princi- 
pally through the operation of the imagination), while Reid declines to offer any such explanations of the origins of his first principles.

It is such a refusal that has given rise to the charge of mysterianism against Reid:

Whatever latent properties there are to mind are in principle undiscoverable, and so should not be the subject of philosophical speculation. There is no means of moving from taxonomy to inquiry into the possible existence of underlying general laws. The 'how'-question that Reid himself takes to be definitive of all philosophical inquiry is unanswerable when it comes to perception, memory, imagination, belief in testimony, and inductive reasoning. That is to say, it is unanswerable quite generally in a science of the mind. (James Harris, "Reid on the Character of a Science of the Mind," 6, quoted in Copenhaver)

As Rebecca Copenhaver notes, there are several grounds for thinking that Reid holds that mental phenomena do not admit of the kinds of explanation found in the physical sciences: the absence of laws or informative generalisations concerning mental states (where this would include, but not be limited to, psychophysical laws); the absence of reductive explanations in Reid's science of the mind; a pious respect for the complexity of God's work combined with an acknowledgement of the limitations of the human mind and science; a concern that a causal explanation of the beliefs will undermine the appearance of them being warranted, and so on. Whether one reads this strand in Reid in a positive light, with Nicholas Wolterstorff, or in a negative, the important (if more limited) point for us is that Reid refuses to offer an account of the origin of the beliefs in first principles in terms of prior mental states or physical causes. $^{2}$

This is a recurring theme throughout Reid's writing, as these two passages from the Essays on the Intellectual Powers and the Essays on the Active Powers demonstrate:

But, whatever be the nature of those impressions upon the organs, nerves, and brain, we perceive nothing without them. Experience informs that it is so; but we cannot give a reason why it is so. In the constitution of man, perception, by fixed laws of nature, is connected with those impressions; but we can discover no necessary connection. The Supreme Being has seen fit to limit our power of perception; so that we perceive not without such impressions; and this is all we know of the matter. (EIP 2.3)

That there is an established harmony between our willing certain motions of our bodies, and the operation of the nerves and muscles that produces these motions, is a fact known by experience. This volition is an act of the mind. But whether this act of the mind have any physical effect upon the nerves and muscles; or whether it be only an occasion of their

2 See Wolterstorff (2001). 
being acted upon by some other efficient, according to the established laws of nature, is hid from us. So dark is our conception of our own power when we trace it to its origins. (EAP 1.8)

Here we find Reid refusing to engage in theorising about the facts concerning the relationship between physiological processes and perceptual experience on the one hand, and volitions and bodily movements on the other. While it might be tempting to treat these as instances of Reid's commendable refusal to engage in metaphysical speculation within scientific contexts on Newtonian grounds, it is plausibly more appropriate to read these as refusals to engage in legitimate scientific theorising about phenomena that clearly fall within the scope of the science of humankind.

This is Louis Loeb's view. Loeb holds that by "claiming that psychological mechanisms are beyond our grasp" (Loeb, 75), Reid gives illegitimate support to his own theory of first principles. If one cannot even in principle begin to investigate the psychological mechanisms that underpin or give rise to the first principles, then the apparent possibility that scientific investigation of the operations of the mind might undermine the status or independence of the principles is ruled out.

Reid's first principles cannot suffer [this] disadvantage. He forecloses any appeal to empirical psychology to call the epistemic status of any of his first principles into question. ...

There is a second way in which the doctrine of the incomprehensibility of the mind shelters Reid's multiplication of first principles. ... If the operative mechanisms are for us a black box, empirical psychology is powerless to support a reduction by resolving one first principle into another. Nor can we compare mechanisms in order to spot ones that might strike us as outliers. (76)

Reid's first principles are therefore shielded from whatever results future progress in psychology might throw up. While one might wonder whether beliefs generated by the imagination on the basis of a transfer of vivacity grounded in a repetition of impressions and ideas could even in principle be warranted, no similar concern can arise for Reid's first principles. Such challenges or worries are simply ruled out by Reid's locating the workings of the mind beyond human comprehension. This, Loeb claims, "is a breach in Reid's naturalism" (76). As a result of this, Loeb sees Hume as the better naturalist philosopher of mind: he opens up the black box and postulates mechanisms that explain the origins of core beliefs, through the transfer of vivacity between impressions and ideas, etc., and identifies connections between the different beliefs. Whatever the merits of Hume's theory, at the very least it is a theory that sits within a naturalistic, scientific framework. 


\section{The Role of Instinct in Reid's Account of Infant Development}

If Loeb is correct about Reid's attitude to any attempts to engage in an exploration of the psychological mechanisms relating to the first principles, then he is surely right that Hume wins the best Scottish naturalistic philosopher of the eighteenth century award. However, there are other factors that we have to take into account if we are to have a fuller picture of Reid's attitude towards the explanation of first principles in front of us. I want to gesture briefly towards two relevant points before attempting to develop another line of response.

Firstly, it is possible to find textual grounds for rejecting the reading of Reid as a mysterian. Rebecca Copenhaver develops several strong lines of argument in response to Harris and others in her 2006 article 'Is Thomas Reid a Mysterian?'. I do not intend to rehearse them here, not least as they are not directed towards Loeb's specific criticism. Nevertheless, it is worth recognising that Copenhaver demonstrates that Reid's account of the mind is wholly in keeping with his particular Newtonian commitments. Reid, Copenhaver claims, "does not hold that mind, more than body, resists explanation by the new science" (449). Both domains admit of causal explanations, even though causation itself is fundamentally mysterious and any attempts to explain it further breach Newtonian principles against metaphysical speculation. Reid can maintain this position because his account of causation is not necessitarian through and through: a true cause is an exercise of active power and thus is not itself necessitated. Accordingly, the laws of nature - the observable regularities in God's behaviour, for Reid - are only contingently, but not metaphysically, necessary.

We can also find many passages in Reid that seem far removed from what might be expected from someone who holds that science cannot tell us anything about the operations of the mind:

What is necessary for the conduct of our animal life, the bountiful Author of Nature hath made manifest to all men. But there are many other choice secrets of Nature, the discovery of which enlarges the power and exalts the state of man. These are left to be discovered by the proper use of our rational powers. They are hid, not that they may be always concealed from human knowledge, but that we may be excited to search for them. This is the proper business of a Philosopher, and it is the glory of a man, and the best reward of his labour, to discover what Nature has thus concealed. (EIP 2.18)

The second point relates to Reid's conception of his wider project. Reid, "in his search for first principles of common sense ... is seeking, 
like Hume, to draw a map of human nature" (Broadie, 108). As McDermid puts it, Reid's main aim is "to establish a sceptic-proof scheme in which ordinary perception, science, morality, and religion are understood not as enemies or rivals, but as different branches of a single tree" (21). Reid is a scientist of human nature every bit as much as he is an epistemologist or metaphysician: his commitment to Newtonian principles is explicit and runs through his entire oeuvre. Newton's first rule is "a golden rule; it is the true and proper test, by which what is sound and solid in philosophy may be distinguished from what is hollow and vain" (EIP 1.3). As Paul Wood writes, "[b]y 1729 he was deeply immersed in the study of the mathematical technicalities of Newton's Principia and, for the rest of his life, Reid investigated an array of empirical and theoretical problems set by Newton in astronomy, mechanics, and optics" (Wood, 57). Reid's project is a Newtonian one to the core; we should not take lightly any suggestion that he would willingly and knowingly set aside these principles upon turning his attention to the operations of the mind in relation to the first principles. ${ }^{3}$

Of course, these considerations are far from conclusive: it is entirely possible that Reid held a deep commitment to naturalism and Newtonianism yet, as Loeb put it, that he breached this commitment in this particular case, implausible as this might otherwise appear.

A better way of approaching this issue is, I believe, to try to extract a picture of the kinds of explanation that Reid is willing to entertain with respect to the first principles from his discussion of the origin of our idea of active power. Reid holds that we have no direct conception of our active power, only a relative one:

Power is not an object of any of our external senses, nor even an object of consciousness. (EAP 1.1)

Nevertheless,

we have very early, from our constitution, a conviction or belief of some degree of active power in ourselves. This belief, however, is not consciousness: For we may be deceived in it; but the testimony of consciousness can never deceive. (EAP 1.1)

Where does the conception of, and belief in, our own power come from? In both the Essays on the Active Powers and in his later paper 'Of Power', Reid provides some comments on the origins of the belief in the sixth principle. There is a "principle, which appears very early in the mind of man, ... that we are efficient causes in our deliberate and volun-

3 See also Laudan (1970), McMullin (2001), Ducheyne (2006) and Lindsay (2013). 
tary actions" (EAP 4.2). This belief is grounded in the experience of one's own activity:

From the consciousness of our own activity, seems to be derived not only the clearest, but the only conception we can form of activity, or the exertion of active power. (EAP 1.5)

Clearly, this needs unpacking: a superficial reading would have Reid holding both that one only grasps that one possesses active power after one becomes aware of one's exertions of said power, and that the exercise of an active power presupposes a grasp of the fact that one is in possession of active power. This is, of course, not what Reid intends. This is made explicit in his later development of this story further in 'Of Power'. Here we read of infants engaging in undirected exertions, only consequently being able to correlate the exertions with the bodily actions they bring about. What this demonstrates is that for Reid, humans are from the outset, and prior to their grasp of the sixth first principle, active.

I am rather inclined to think that our first exertions are instinctive, without any distinct conception of the event that is to follow, consequently without will to produce that event. And that finding by experience that such exertions are followed by such events, we learn to make the exertion voluntarily and deliberately, as often as we desire to produce the event. And when we know or believe that the event depends upon our exertion, we have the conception of power in ourselves to produce that event. ('Of Power', 3$)^{4}$

We find infants engaging in blind exertions - what we might think of flailings, the kind that find parents poked in the eye and kicked on the chest - and only later come to develop a grasp of the correlations between the exertions and bodily movements to such an extent that they can move their limbs at will. We can imagine Reid, the astute observer of human behaviour, watching his nine children in their infancy as they develop control over their actions and acquire a sense of agency. It is crucial to recognise that the child does not possess full agency; there is no conception of what is willed, and so the child cannot possess the liberty of a moral agent. The account is grounded in our ability to engage (or refrain from engaging) in some rudimentary form of activity at a more basic developmental stage than the possession of agency as described earlier. ${ }^{5}$ On the story Reid offers, this knowledge of our own agency, and

4 Henceforth 'OP'.

5 Thus I disagree with Gideon Yaffe when he writes "the baby, for instance, notices that the hand moves following the instinctive exertion to move it, but there is no reason to think that the baby is active with respect to the movement" (Yaffe, 27). 
thus the belief picked out by the sixth first principle, arises from experience; it is not innate, nor does it appear in a vacuum.

This infant behaviour is nonintentional, an example of the kind of instinctual behaviour outlined above. The exertion is mere "natural blind impulse" with no "end in view" or deliberation. The infant possesses both a rudimentary form of active power and a natural inclination to exert the power, even in the absence of any knowledge of possible outcomes. Human beings, on Reid's picture, are fundamentally active, selfmoving creatures, and this is still true prior to the acquisition of capacity for understanding.

This account of the origin of our conception of power, makes it to be the fruit of experience and not innate; though it must be as early as any deliberate voluntary exertion to produce a certain event. (OP 3)

Reid's story, grounded in instinctual behaviour - however brief it may be - gives us an account of the development of (and, accordingly, necessary preconditions for) the possession of the belief captured by first principle number six. What it also demonstrates is the kind of explanation that Reid thinks appropriate for the first principles: it is not reliant on the postulation of relations between psychological states and mechanisms in the way that Hume's explanations are; rather, it looks towards observable, empirical evidence from human behaviour (in this case, infant development) in order to determine the actual conditions under which such beliefs do and must arise. It does not seem wildly implausible to suggest that this Reidian form of explanation is of a legitimate, scientifically respectable sort.

\section{Explanation and Foundationalism in Hume and Reid}

What we see here is, I want to suggest, a dispute concerning what scientifically respectable explanations of natural or instinctual beliefs should look like. The differing conceptions in play reflect the epistemologies of the respective philosophers. In the case of Hume, we find:

i. explanations that look toward the inner operations of the mind, these uncovered through introspection rather than behavioural and publicly accessible evidence; and

ii. the favouring of explanations grounded in a conception of perception as intrinsically passive and deterministic.

This allows Hume to look for necessitated (at least in the Humean sense) psychological operations where we can find causal relations between types of psychological state. So, repeated correlations cause the mind to form expectations and to transfer vivacity, resulting in the cre- 
ation of new beliefs, and so on. It is this kind of explanation that Loeb gives credit for; we are looking inside the black box, at the causally necessitated mechanisms and the perceptions upon which they operate. This, Loeb appears to hold, is a true naturalistic psychology.

It is certainly the case that Reid eschews such forms of explanation. Whether this is due to a genuine mysterianism, or a legitimate epistemic humility that recognises the failings of eighteenth century theories of the mind combined with a commitment to a form of Newtonianism hostile to metaphysical speculation is up for debate; the crucial point is that Reid rejects the explanatory paradigm favoured by Hume and praised by Loeb.

The account of the origins of the awareness of agency discussed above looks towards different kinds of evidence. Reid does allow introspective evidence - in fact, as with Hume, this he treats this as the most important kind - but his evidence is not restricted to this. In its place, we find the kind of wide-ranging search for empirically accessible evidence that characterised the hunt for first principles. In particular, we have:

i. explanations that admit empirical evidence from a wider range of sources, including publicly available behavioural evidence; and

ii. the permitting of explanations that ascribe a non-necessitarian active power to the subjects of study.

In a wider discussion of the respective merits of the two philosophers Penelope Maddy argues that Reid is the better scientist of humanity. Lying behind this claim is not just Hume's failure to question the commitment to a widely-held, problematic perceptual theory that reifies perceptions; rather, the major difference concerns the methodologies of the two contemporaries. The true point of divergence is Reid's rejection of a Cartesian model of introspection as the primary means of knowledge acquisition. Not only does this appear to open the doors to sceptical challenges, it cripples the study of humankind from the outset: ${ }^{6}$

In place of the restricted Cartesian perspective, Reid proposes to begin by trusting to the general reliability of all his faculties - 'that furniture which nature hath given to the human understanding ... a part of our constitution ... the common sense of mankind.' His disagreement with Hume over the Theory of Ideas is a mere footnote to this fundamental shift. (Maddy, 32)

If Maddy's analysis is right, then once we are free from the grasp of this Cartesian foundationalism, we are able to engage in a search for explanation that utilises the full resources of all of the sciences. There is

6 As Maddy correctly notes in her insightful analysis, just this kind of scepticism plays a vital role in Hume's route to his naturalism (Maddy, 33). 
no longer any need to restrict oneself merely to the inspection of one's own mental operations. By also admitting the sorts evidence from sociology, anthropology, linguistics and certain kinds of psychology, Reid can engage in the proper observation of humankind. This allows Reid to produce a better naturalistic, scientific account of the origins of our beliefs and the operations of the mind. One might still worry that Hume does something that Reid does not: he tells us about what is going on within the mind. But we should not forget that he does so only by reifying perceptions and postulating speculative mechanisms - specifically the imagination - for which we have no empirical evidence, and which, looked at on their own terms, appear deeply suspect. The kinds of evidence Reid endorses should be enough for any eighteenth century philosopher.

Turning to the second feature of the respective forms of explanation above, the passivity or otherwise of the mind, we can see how different views on this could have a significant impact on the forms of explanation that are seen as admissible. On the Humean model of the mind, all observation is fundamentally passive, including the introspective observation of one's own mind. The appearance and ordering of perceptions is determined by a combination of external stimuli (or "unknown causes", as Hume has it) ${ }^{7}$ and the principles governing the association of ideas. The subject has no further ability to influence the manner in which impressions and ideas enter in her mind. Furthermore, we cannot even grasp what such power would amount to: we do not observe power, nor can we infer it.

\begin{abstract}
All ideas are deriv'd from, and represent impressions. We never have any impression, that contains any power or efficacy. We never therefore have any idea of power. ( $\mathrm{T}$ 1.3.14.11)

Some have asserted, that we feel an energy, or power, in our own mind; and that having in this manner acquir'd the idea of power, we transfer that quality to matter, where we are not able immediately to discover it. ... In short, the actions of the mind are, in this respect, the same with those of matter. We perceive only their constant conjunction; nor can we ever reason beyond it. No internal impression has an apparent energy, more than external objects have. (T 1.3.14.12, App.)
\end{abstract}

Once such a conception of introspective awareness is in place, any explanation of the Reidian sort that makes essential reference to one's active power is ruled out. Instinctive exertions, the blind exercise of one's active power, are a fiction. We can have no idea of any such thing, therefore there is nothing to play the necessary explanatory role.

$7 \mathrm{~T}$ 1.1.2.1. I follow standard conventions for citing Hume's Treatise: book, part, section, paragraph. 
As we have seen, Reid rejects this perceptual model, thus he is able to allow that experience can deliver us knowledge of our own agency. For Reid, voluntary activity wears its connection to power on its sleeve, 'it somehow smacks of power', as Van Cleve has it (373). One cannot be aware of one's voluntary activity without being aware of one's power. The awareness of the relationship between exertion and bodily movement is not a case of the agent passively observing a relation of constant conjunction. The agent's awareness of her power (including power as instinctively exercised) is somehow built in to the nature of the experience of acting. This thought might appear mysterious if we have the classic Humean/empiricist account of experience in mind; but this is precisely what is at stake. Experience, especially experience of one's activity, need not and ought not be construed on the passive perceiver model.

Stuart Hampshire makes just this criticism against twentieth century empiricist thought:

The deepest mistake in empiricist theories of perception ... has been the representation of human beings as passive observers receiving impressions from 'outside' of the mind, where the 'outside' includes their own bodies. In fact I find myself from the very beginning able to act upon objects around me. In this context to act is to move at will my own body, that persisting physical thing, and thereby bring about perceived movement of other physical things. I not only perceive my body; I also control it; I not only perceive external objects, I also manipulate them. ... I find myself living in a medium of physical action and reaction, and I do not always need to infer from my observations alone that I have made a movement of some particular kind. This felt resistance to my will defines for me, in conjunction with my perceptions, my own situation as an object among other objects. Both perceptions and bodily sensations contribute to this elementary discovery; even taken together, they do not constitute the whole of it. I know directly, that I tried, or set myself, to move... No knowledge is more direct and underived than this knowledge. (Hampshire, 47-8)

If we reject the two tenets of Humean theory discussed above, the Reidian approach to explanation appears more compelling. We can investigate the operations of the mind, including questions about the origins of, and necessary conditions for, belief in the first principles, by using all the resources of science. There is no need to cripple one's investigations from the outset by committing oneself to an implausible Cartesian starting point; nor need the scientist of humanity start by attempting to fend off the scepticism that this invites in. When we take these factors into account, Hume's methodology for the study of the mind seems far less appealing. In comparison to an implausible account based around the transfer of vivacity by the imagination, Reid's failure to posit internal mechanisms seems downright virtuous. That is not and should not 
be what we want from an eighteenth century theory of the mind, not if we want it to have lasting value. It is no wonder that Maddy finds Reid to have more in common with contemporary scientists; he is the better student of human nature. ${ }^{8}$

\section{Bibliography}

Broadie, Alexander. The Tradition of Scottish Philosophy. Edinburgh: Polygon, 1990.

Copenhaver, Rebecca. "Is Thomas Reid a Mysterian?" Journal of the History of Philosophy 44, no. 3 (January 2006): 449-466.

Ducheyne, Steffen. "Reid's adaptation and radicalization of Newton's natural philosophy," History of European Ideas 32, (2006): 173-189.

Hampshire, Stuart. Thought and Action. London: Chatto and Windus, 1959.

Harris, James A. Of Liberty and Necessity: The Free Will Debate in Eighteenth-Century British Philosophy. Oxford: Oxford University Press, 2005.

Hume, David. A Treatise of Human Nature. 1739. Edition cited: L.A. Selby-Bigge and P.H. Nidditch (eds.), Oxford: Oxford University Press, 1978.

Laudan, Larry. "Thomas Reid and the Newtonian Turn of British Methodological Thought." In R.E. Butts and J.W. Davis (eds.), The Methodological Heritage of Newton. Toronto: University of Toronto Press, 1970: 103-131.

Lindsay, Chris. "Hume and Reid on Naturalism, Liberty and Necessity." In I. Kasavin, (ed.), David Hume and Contemporary Philosophy. Newcastle Upon Tyne: Cambridge Scholars Publishing, 2012.

Loeb, Louis. "The naturalisms of Hume and Reid." Proceedings and Addresses of the APA 81, no. 2 (November 2007): 65-92.

Maddy, Penelope. "Naturalism and common sense." Analytic Philosophy 52, no. 1 (2011): 2-34.

McDermid, Douglas. The Rise and Fall of Scottish Common Sense Realism. Oxford: Oxford University Press, 2018.

McMullin, Ernan. “The impact of Newton's Principia on the philosophy of science." Philosophy of Science 68 (2001): 279-310.

Reid, Thomas. An Inquiry into the Human Mind on the Principles of Common Sense. 1764. Edition cited: D.R. Brookes (ed.), Edinburgh: Edinburgh University Press, 1997.

Reid, Thomas. Essays on the Intellectual Powers of Man. 1785. Edition cited: D.R. Brookes and K. Haakonssen (eds.), Edinburgh: Edinburgh University Press, 2002.

8 This paper is based on a presentation given at a workshop on Scottish Enlightenment thought at the Uniwersytet Mikołaja Kopernika, Toruń on 26 May 2018. I am truly very grateful to Adam Grzeliński and Anna Markwart for the opportunity to present this talk and their gracious assistance. 
Reid, Thomas. Essays on the Active Powers of Man. 1788. Edition cited: K. Haakonssen and J.A. Harris (eds.), Edinburgh: Edinburgh University Press, 2010.

Reid, Thomas. “Of Power.” Philosophical Quarterly 51, no. 202 (January 2001): 1-12. (Written 1792).

Rowe, William L. "Thomas Reid's Theory of Freedom and Responsibility." In T. Cuneo and R. van Woudenberg (eds.), The Cambridge Companion to Thomas Reid. Cambridge: Cambridge University Press, 2004.

Van Cleve, James. Problems from Reid. Oxford: Oxford University Press, 2015. Wolterstorff, Nicholas. Thomas Reid and the Story of Epistemology. Cambridge: Cambridge University Press, 2001.

Wood, Paul. "Thomas Reid and the culture of science." In T. Cuneo and R. van Woudenberg (eds.), The Cambridge Companion to Thomas Reid. Cambridge: Cambridge University Press, 2004.

Yaffe, Gideon. Manifest Activity: Thomas Reid's Theory of Action. Oxford: Oxford University Press, 2004.

\section{Summary}

In his account of what he calls the 'mechanical principles' of action, Thomas Reid distinguishes between deliberate, willed actions and those caused by instincts or habits. He holds that that agents can only be held morally responsible with respect to willed actions, as it is only in such cases that the agent acts freely on his libertarian model of agency. Nevertheless, in his later writings Reid seems to suggest that instinctual behaviour is both prior to and a precondition for the performance of free action. In this brief paper, I want to first introduce Reid's theory of action and then expand upon this account in order to show that it goes some way to mitigate the criticisms raised by Louis Loeb and others against Reid, namely that Reid is content to rest with an account that rejects any attempt to explain the origin of beliefs that arise from human nature. Loeb portrays Hume as the superior philosopher due in part to his willingness to open up the black box of the mind for scientific inspection. I want to claim that Loeb misses the mark here; despite the fact that Hume does attempt to give us a psychological account of the origins of certain beliefs, it is crippled by the implausible restrictions Hume places on his system. Reid's account, in contrast, employs a different conception of explanation and, as a result, offers a more plausible account that is not hindered by an unnecessary emphasis on introspection.

Keywords: Thomas Reid, agency, human nature, instinct, explanation, Scottish philosophy 


\section{Streszczenie}

\section{Instynkt i wyjaśnienie w Thomasa Reida teorii działania}

W swym opisie tego, co nazywa „mechanicznymi zasadami” działania, Thomas Reid rozróżnia działania rozmyślne, wolicjonalne i te, które są wynikiem instynktu bądź nawyku. Twierdzi, że podmiot działający można uznać za odpowiedzialny moralnie jedynie za działania wolicjonalne, gdyż w przyjętym przezeń libertariańskim modelu działania tylko w ich przypadku można mówić o wolności. Niemniej jednak w swych późniejszych pismach Reid wydaje się sugerować, że takie instynktowne działanie jest wcześniejsze w stosunku do działania wolnego, a także je warunkuje. W swym krótkim artykule przedstawiam Reidowską teorię działania, następnie zaś staram się omówić ją tak, aby osłabić krytykę Reida przedstawioną przez Louisa Loeba i innych. Twierdzą oni, że Reid zadowala się takim opisem działania, które odrzuca jakąkolwiek próbę wyjaśnienia przekonań mających swe źródło w ludzkiej naturze. Loeb uznaje, że Hume jako filozof przewyższa Reida z tego względu, że do pewnego stopnia udaje mu się poddać badaniu naukowemu czarną skrzynkę ludzkiego umysłu. Uważam, że Loeb nie ma w tym względzie racji. Chociaż Hume rzeczywiście usiłuje podać psychologiczny opis powstania pewnych przekonań, jest on jednak ułomny ze względu na ograniczenia, jakie Hume narzuca na swój własny system. Opis Reida zawiera odmienne pojęcie wyjaśnienia; jest on bardziej przekonujący, ponieważ nie ogranicza go zbędne podkreślanie roli introspekcji.

Słowa kluczowe: Thomas Reid, działanie, ludzka natura, instynkt, wyjaśnienie, filozofia szkocka 